\title{
The Effects of Propolis Extract Administration on HIV Patients Receiving ARV
}

\author{
Erwin Astha Triyono ${ }^{1,2 *}$, Sarah Firdausa ${ }^{3}$, Heru Prasetyo $^{4}$, Joni Susanto $^{5}$, James Hutagalung $^{4}$, \\ Lilis Masyfufah ${ }^{6}$, Budiono $^{7}$, Ivan Hoesada ${ }^{8}$ \\ ${ }^{1}$ Division of Tropical and Infectious Diseases, Department of Internal Medicine, Faculty of Medicine, Universitas Airlangga, \\ Campus A, Jl. Mayjen Prof. Dr. Moestopo No. 47, Surabaya 60131, Indonesia \\ ${ }^{2}$ Department of Internal Medicine, Dr. Soetomo General Hospital, Jl. Mayjen Prof. Dr. Moestopo No. 6-8, Surabaya 60286, Indonesia \\ ${ }^{3}$ Department of Internal Medicine, Faculty of Medicine, Universitas Syiah Kuala, Jl. Teuku Tanoh Abee, Banda Aceh 24415, Indonesia \\ ${ }^{4}$ Department of Parasitology, Faculty of Medicine, Universitas Airlangga, Campus A, Jl. Mayjen Prof. Dr. Moestopo No. 47, Surabaya 60131, Indonesia \\ ${ }^{5}$ Department of Anatomy and Histology, Faculty of Medicine, Universitas Airlangga, Campus A, Jl. Mayjen Prof. Dr. Moestopo No. 47, \\ Surabaya 60131, Indonesia \\ ${ }^{6}$ STIKES Yayasan RS Dr. Soetomo, Jl. Mayjen. Prof. Dr. Moestopo No. 8 A, Surabaya 60286, Indonesia \\ ${ }^{7}$ Department of Public Health, Faculty of Medicine, Universitas Airlangga, Campus A, Jl. Mayjen Prof. Dr. Moestopo No. 47, Surabaya 60131, Indonesia \\ ${ }^{8}$ PT Harmoni Dinamik Indonesia, Jl. Probolinggo No.18, Menteng, Jakarta 10350, Indonesia \\ *Corresponding author. E-mail: erwintriyono@yahoo.com
}

Received date: Sep 1, 2020; Revised date: Jan 4, 2021; Accepted date: Jan 7, 2021

\section{Abstract}

B ACKGROUND: Human Immunodeficiency Virus (HIV) is an infectious disease that targets the human immune system by attacking cluster of differentiation (CD) 4 cells. The use of propolis in HIV patients is expected to be safe and beneficial in terms of increasing endurance and immunity by its role in increasing CD4 level. This study aimed to analyze the influence of propolis supplementation in increasing the CD4 level in anti-retroviral (ARV)-treated HIV patients.

METHODS: Double-blind randomized controlled clinical trial was conducted in $50 \mathrm{HIV}$ patients who took regular ARV therapy. The subjects were divided into two groups, one group was treated with ARV and propolis, while another one was given ARV and placebo. The CD4 cell count was measured during pre-treatment, in the $3^{\text {rd }}$ month, in the $6^{\text {th }}$ month after treatment. The level of hemoglobin, leukocyte, and platelets were also measured. The SF-12 questionnaire was used to evaluate quality of life of the subject.

RESULTS: Out of 50 subjects, 43 subjects completed the study, which were 19 subjects from the propolis group and 24 subjects from the placebo group. After 3-month of treatment, there was a statistically significant difference in the increase of CD4 level in propolis group, while the increment was not significant in the placebo group. After 6-month treatment, the increase of CD4 level was occurred in both groups, propolis and placebo, however the increment was not statistically significant. The levels of hemoglobin, leukocyte, and platelets were not altered by the treatment and remained normal throughout the study. The quality of life was improved during the study; however, it was also not statistically significant. Mild adverse events occurred in 3 subjects which were relieved after the treatment stopped.

CONCLUSION: Based on the result of this study, the administration of propolis on HIV patients receiving ARV bring significant difference in the increase of CD4 in propolis group from baseline to 3 month after the treatment. While in placebo group, this increment was not significant. At the end of study, CD4 count continued to rise up, however the increase was not statistically significant. There are no hemoglobin, leukocyte, platelets, and quality of life abnormalities. Therefore, it is necesary to do further research with a spesific CD4 count. However, it may be beneficial in relieving the clinical symptoms and quality of life of patient living with HIV.

KEYWORDS: CD4, ARV, HIV, propolis

Indones Biomed J. 2021; 13(1): 75-83 


\section{Introduction}

Complementary and alternative treatments in the treatment of Human Immunodeficiency Virus (HIV) have been widely used these days. The most common and rapidly developed alternative modality is herbal medicine. The use of herbal medicine remains high among the patients infected with HIV, even though they had received effective anti-retroviral (ARV) therapy.(1) Currently, there is a trend to combine ARV with other supplements, such as propolis. A study conducted in HIV patients treated with ARV reported that the use of alternative and supplements therapy was around $56.49 \%$ and $36.64 \%$, respectively.(2)

Herbals are used as widely used as supplements in treating HIV because they increase the immune system; minimize the side effects of ARV such as nausea, dizziness, skin rash, and depression; and decrease the virus replication so then increasing the patients' health status. Another report also mentioned it benefits for the immune system, such as improving the anti-oxidant status, and helping the antiretroviral activities.(3)

Propolis contained more than 300 constituents that had been proven in vitro of having the ability in inhibiting the enzyme of HIV replication. $(4,5)$ Some active compounds of propolis reported of having anti-HIV activities arer flavonoids, caffeic acid, p-coumaric acid, quercetin, naringenin, isorhamnetin and some other compounds.(6)

The mechanism of anti-HIV activities from the propolis components is based on the principle of a structureactivity relationship (SAR). SAR is the relationship between the chemical structure and the pharmacological activities of a component. Its experimental model could explain the quantitative relationship between the structure of molecules and the biological activities of molecules.(7) Caffeic acid phenethyl ester (CAPE) is the phenolic acid component of propolis which may have anti-HIV activities, in-vitro, based on the structure-activity relationship. The structure of CAPE, in form of hydroxyls, was able to inhibit the activity of integrase using the integrase transfer strand inhibitors, one of the mechanisms of action of integrase that disrupted the integrase activities. $(8,9)$

Propolis supplementation combined with the standard ARV therapy is expected to be able to influence the process of virus replication that indirectly supports the increase of total cluster of differentiation (CD) 4 cell. However, it is remains unknwon whether the supplementation of propolis on top of standard ARV regimen has a good effect on HIV patients, clinically and immunologically. It needs to be evaluated in order to clarify the misjudgment and the distrust in using this supplement in HIV patients. Hence, this clinical trial was conducted to evaluate the beneficial effect of propolis supplementation on CD4 level as well as the safety and health status of HIV patient on ARV therapy.

\section{Methods}

\section{Study Design and Subjects Selection}

This was a double-blind controlled trial involving $50 \mathrm{HIV}$ patients who had received ARV in the Outpatient Polyclinic of UPIPI, Rumah Sakit Dr. Soetomo, Surabaya, Indonesia. The patients who fulfilled the requirements were in the study. The inclusion criteria were age above 21 years old and underwent the ARV therapy without concerning the total CD4 levels. Patients with allergy in their medical history, pregnant women, and those with opportunistic infections were excluded. The criteria for determining opportunistic infections were made based on the WHO clinical staging of HIV.(10) The subjects would be dropped out if they experienced any adverse event, pregnant, or those who did not follow the study protocol. The subjects were divided into two groups, the subjects in group A received the combination of ARV and propolis, while in group B received ARV and placebo for 6 months.

This research was approved by the ethical committee of Rumah Sakit Dr. Soetomo, Surabaya, Indonesia (228/ Panke.KKE/III/2016) and it complies with the principles of Good Clinical Practice. Informed consent was obtained from all research subjects.

\section{Data Collection}

In the first visit, complete medical history, quality of life parameters and laboratories markers (CD4, hemoglobin, leukocyte, and platelets) were assessed. All of those parameters were conducted at month 0 (baseline), month 3 , month 6 of the study. During monthly visit, the body weight was measured and each complaint, sign, or medical symptoms were recorded.

The primary end-point of this research was CD4 level changes before and after administration of research product. The CD4 levels were measured using the Multicolor Flowcytometry FACS Calibur (BD Bioscience, San Jose, CA, USA). The other end-point were body weight, blood profile (hemoglobin, leukocyte, platelets), and quality of life of the subjects.

Clinical contidion and complaints were measured by conducting an interview and assessing health status 
by using the 12-Item Short Form Health Survey (SF-12) questionnaire. The interview was guided by a questionnaire containing 18 questions related to subjective complaints and clinical symptoms. This questionnaire was intended to evaluate the clinical conditions before, during, and at the end of the study. Meanwhile, the measurement of the subjects' quality of life was also assessed based on the survey of health status by using the SF-12 questionnaire. It consisted of 6 question items related to physical health component (physical component score/PCS) and 6 question items related to mental health component (mental component score/MCS).(11)

\section{Research Product}

Propolis used in this research was supplied by PT Harmoni Dinamik Indonesia (HDI Group, Jakarta, Indonesia) which was known as HDI Propoelix ${ }^{\circledR}$. The propolis was packed in transparent vegacaps (200 mg per capsule) and was given to patients with a total dosage of $600 \mathrm{mg}$ daily or 3 times of $200 \mathrm{mg}$ per day. It was taken 2 hours after having ARV. Meanwhile, placebo was also packed and given in the sameway as HDI Propoelix ${ }^{\circledR}$.

\section{The Safety Assessment of Research Product}

The safety of research products was assessed in all patients during the study. Any adverse event, such as gastrointestinal symptoms, dizziness, skin rash, and the changes of vital signs, was recorded. The levels of hemoglobin, leukocyte, and platelets were also assessed.

\section{Statistical Analysis}

The data were analyzed using SPSS version 23.0 for Windows (IBM Coorporation, Armonk, NY, USA) and were presented as mean \pm standard deviation (SD), median (minimum-maximum/range), or proportion $(\mathrm{n}(\%))$. The statistical analysis was done using the paired T-test as a parametric statistic and the Wilcoxon signed-rank test as a non-parametric statistic for paired samples. While for comparing the data of the propolis group and placebo group, the independent sample T-test, and Mann-Whitney test were used. The statistical significance level was determined at a $p$-value $<0.05$.

\section{Results}

Initially, there were 50 subjects involved in this research, 25 subjects in each group. Subject characteristics at baseline were presented in Table 1. Forty-three subjects completed the research until the end-point (month 6), while 7 subjects were dropped during the study. Six subjects from propolis group were excluded due to allergy (3 subjects), being pregnant (2 subjects), and loss to follow up (1 subject), while 1 subject from placebo group was excluded due to pneumonia infection. The data of excluded subjects were not included in final statistical analysis.

Analysis showed no significant differences between the subjects both groups, based on age, educational level, marital status, smoking status, and body weight.

Table 1. Subject characeristic at baseline.

\begin{tabular}{|c|c|c|c|}
\hline Variabel & $\begin{array}{c}\text { Propolis } \\
(n=25)\end{array}$ & $\begin{array}{c}\text { Placebo } \\
(n=25)\end{array}$ & $p$-value* \\
\hline Age (years old), median (range) & $36.8(23-51)$ & $37.1(18-51)$ & 0.882 \\
\hline Gender, n (\%) & & & 1.000 \\
\hline Male & $11(44.0)$ & $12(48.0)$ & \\
\hline Female & $14(56.0)$ & $13(52.0)$ & \\
\hline Education, n(\%) & & & 0.322 \\
\hline Elementary & $2(8.0)$ & $4(16.0)$ & \\
\hline Junior/Senior high & $17(68.0)$ & $17(68.0)$ & \\
\hline Higher education & $6(24.0)$ & $4(16.0)$ & \\
\hline Marital Status, n (\%) & & & 0.509 \\
\hline Married & $16(64.0)$ & $15(60.0)$ & \\
\hline Single & $4(16.0)$ & $7(28.0)$ & \\
\hline Divorce & $5(20.0)$ & $3(12.0)$ & \\
\hline Smoker(s), n (\%) & $7(28.0)$ & $4(16.0)$ & 0.495 \\
\hline \multicolumn{4}{|l|}{ Body weight (kg), median (range) } \\
\hline Pre & $57.34(41-82)$ & $58.22(42-85)$ & 0.941 \\
\hline Post & $57.00(40-85)$ & $56.30(41-83)$ & 0.881 \\
\hline
\end{tabular}

*Tested with independent T-test, significant if $p<0.05$. 


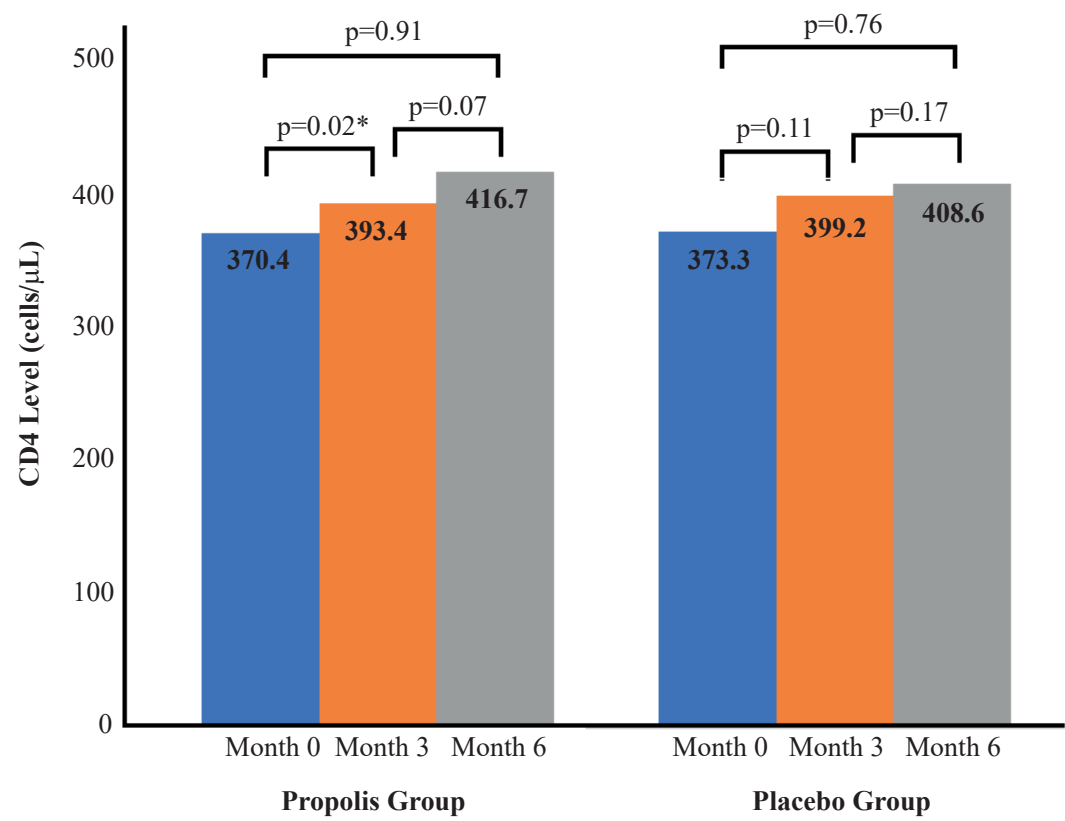

Figure 1. The total CD4 before and after the treatment. *Tested with independent T-test, significant if $p<0.05$.

\section{Total CD4 Cell Before and After Supplementation}

Baseline CD4 cell (pre-treatment) in both groups where below normal limit (the following data was presented as mean \pm SD). The CD4 level cell were $370.4 \pm 253.5$ cells/ $\mu \mathrm{L}$ in propolis group and $373.3 \pm 172.3$ cells $/ \mu \mathrm{L}$ in placebo (Figure 1). It tended to rise up from month 0 to month 3 and month 6 in both groups.

In the propolis group, the CD4 level increased to $393.4 \pm 235.9$ cells $/ \mu \mathrm{L}$ in month 3 , and to be $416.7 \pm 271.8$ cells $/ \mu \mathrm{L}$ in month 6 . In the placebo group, it went up to $399.2 \pm 203.5$ cells $/ \mu \mathrm{L}$ in month 3 and $408.6 \pm 190.5$ cells $/ \mu \mathrm{L}$ in month 6. However, this CD4 count improvement was not statistically significant.

The increase of mean CD4 in propolis group from baseline to month 3 was statistically significant $(p=0.02)$, while in placebo group, this increment was not significant ( $p=0.11$ ). At the end of study, CD4 count continued to rise up to $416.7 \pm 271.8$ cells $/ \mu \mathrm{L}$ in propolis group and $408.6 \pm 190.5$ cells $/ \mu \mathrm{L}$ in placebo group, however this increase was not statistically significant.

\section{Blood Profile Before and After Supplementation}

The blood profile, consisting of hemoglobin, leukocytes, and platelets, was measured as one of the research objectives in order to ensure research products were safe to use. The result showed that all parameters of blood profile were within normal limit before and after the research product was taken by subjects in both groups (Table 2). There was an increase in the average of leukocytes $(5,334 / \mathrm{uL}$ to 6,437 $/ \mathrm{uL})$ in propolis group which was statistically significant $(p=0.02)$. While in placebo group, the leukocytes were slightly dropped. Both mean of leukocytes were within the normal range.

\section{Clinical Condition of the Subjects}

Subject's complaints were presented in Table 3. Sadness and fatigue were the dominant complaint of subject at the beginning of study (more than $45 \%$ for both groups). Other subjective complaints, such as losing appetite, muscle/joint pain, pain/numbness in the hands and feet, headache, dizziness, digestive problems, impaired memory,

Table 2. The blood profile before and after propolis supplementation.

\begin{tabular}{|c|c|c|c|c|c|}
\hline \multirow{2}{*}{ Variables } & \multirow{2}{*}{ Month } & \multicolumn{2}{|c|}{ Propolis } & \multicolumn{2}{|c|}{ Placebo } \\
\hline & & Median (Range) & $p$-value & Median (Range) & $p$-value \\
\hline \multirow[t]{2}{*}{$\mathrm{Hb}(\mathrm{g} / \mathrm{dL})$} & 0 & $12.8(7.4-16.0)$ & \multirow{2}{*}{0.14} & $12.5(8.1-15.6)$ & \multirow{2}{*}{0.89} \\
\hline & 6 & $13.5(7.85-16.5)$ & & $12.7(7.39-17.1)$ & \\
\hline \multirow[t]{2}{*}{ Leukocyte (/uL) } & 0 & $5,334(1,140-7,740)$ & \multirow{2}{*}{$0.02 *$} & $5,313(1,640-9,520)$ & \multirow{2}{*}{0.23} \\
\hline & 6 & $6,437(933-11,900)$ & & $4,814(5000-8,850)$ & \\
\hline \multirow[t]{2}{*}{ Platelets $\left(\times 10^{3} / \mathrm{uL}\right)$} & 0 & $260(123-440)$ & \multirow{2}{*}{0.62} & $264(170-377)$ & \multirow{2}{*}{0.14} \\
\hline & 6 & $234(121-331)$ & & $257(147-358)$ & \\
\hline
\end{tabular}

*Tested with independent T-test, significant if $p<0.05$. 
Table 3. Subjective complaints before and after the treatment.

\begin{tabular}{|c|c|c|c|c|c|c|c|c|c|}
\hline \multirow{3}{*}{ Subjective Complaints } & \multicolumn{3}{|c|}{ Month 0} & \multicolumn{3}{|c|}{ Month 3} & \multicolumn{3}{|c|}{ Month 6} \\
\hline & \multicolumn{2}{|c|}{ n (\%) } & \multirow[b]{2}{*}{$p$-value } & \multicolumn{2}{|c|}{ n (\%) } & \multirow[b]{2}{*}{$p$-value } & \multicolumn{2}{|c|}{ n (\%) } & \multirow[b]{2}{*}{$p$-value } \\
\hline & $\begin{array}{c}\text { Propolis } \\
(n=19)\end{array}$ & $\begin{array}{c}\text { Placebo } \\
(n=24)\end{array}$ & & $\begin{array}{c}\text { Propolis } \\
(n=19)\end{array}$ & $\begin{array}{c}\text { Placebo } \\
(n=24)\end{array}$ & & $\begin{array}{c}\text { Propolis } \\
(n=19)\end{array}$ & $\begin{array}{c}\text { Placebo } \\
(n=24)\end{array}$ & \\
\hline Feeling sad & $10(52.63)$ & $11(45.83)$ & 1.00 & $1(5.26)$ & $2(8.33)$ & 1.00 & $0(0)$ & $1(4.17)$ & 1.00 \\
\hline Having sleep disorder & $8(42.10)$ & $7(29.17)$ & 1.00 & $2(10.53)$ & $0(0)$ & 0.20 & $0(0)$ & $1(4.17)$ & 1.00 \\
\hline Feeling nervous & $3(15.79)$ & $4(16.67)$ & 1.00 & $0(0)$ & $0(0)$ & - & $0(0)$ & $1(4.17)$ & 1.00 \\
\hline Fatigue & $10(52.63)$ & $10(41.67)$ & 1.00 & $1(5.26)$ & $2(8.33)$ & 1.00 & $0(0)$ & $2(8.33)$ & 0.50 \\
\hline Sexual problems & $1(5.26)$ & $4(16.67)$ & 0.34 & $1(5.26)$ & 0 & 0.46 & $0(0)$ & $0(0)$ & - \\
\hline Dizziness & $7(36.84)$ & $9(37.50)$ & 0.76 & $1(5.26)$ & $1(4.17)$ & 1.00 & $0(0)$ & $2(8.33)$ & 0.50 \\
\hline Headache & $5(26.32)$ & $10(41.67)$ & 0.21 & $1(5.26)$ & $2(8.33)$ & 1.00 & $0(0)$ & $1(4.17)$ & 1.00 \\
\hline Impaired memory & $7(36.84)$ & $8(33.33)$ & 1.00 & $1(5.26)$ & $0(0)$ & 0.46 & $0(0)$ & $1(4.17)$ & 1.00 \\
\hline Digestive problems & $2(10.53)$ & $1(4.17)$ & 1.00 & $1(5.26)$ & $0(0)$ & 0.46 & $0(0)$ & $0(0)$ & - \\
\hline Losing appetite & $7(36.84)$ & $3(12.50)$ & 0.29 & $0(0)$ & $1(4.17)$ & 1.00 & $0(0)$ & $1(4.17)$ & 1.00 \\
\hline Pain/numbness in hands and feet & $9(47.37)$ & $4(16.67)$ & 0.19 & $1(5.26)$ & $2(8.33)$ & 1.00 & $0(0)$ & $0(0)$ & - \\
\hline Muscle/joint pain & $4(21.05)$ & $3(12.50)$ & 1.00 & $0(0)$ & $1(4.17)$ & 1.00 & $0(0)$ & $1(4.17)$ & 1.00 \\
\hline
\end{tabular}

sexual problems, feeling sad, sleep disorders, nervous, and dizziness were also reported by subjects in both groups.

These complaints were improved during the study (less than $10 \%$ subject got complaints in month 3 ) and were relieved at all at the end of the study in propolis group, while in placebo, about $8 \%$ subjects remained fatigue and dizziness. There was no significant difference in the subjective complaint from the propolis group and placebo group at month 0 , month 3 , month 6 of the study (all $p$-values $>0.05$ ).

The clinical symptoms of the subjects were shown in Table 4. Body weight loss, nausea and vomiting were clinical symptoms which affected more than $25 \%$ subjects in both groups at baseline of the study. Other clinical symptoms such as diarrhea, fever, cough/shortness of breath, and skin rash were happened in less than $30 \%$ of the subjects. These symptoms were alleviated during the study (month 3 ) in both groups. At the end of the study, only 1 subject in propolis group which still have clinical symptoms (nausea and vomiting), compared to 4 subjects in placebo group.

\section{Short Form-12 (SF-12)}

Analysis results of MCS and PCS can be found in Table 5 . The MCS was better than the PCS in both groups. All MCS was above 50 which mean the all the subject in both groups have good mental health since the study was begin until the end of the study.

Generally, the PCS in both groups were fair, as the mean score of PCS was below 50. There was an increase of PCS in both groups throughout the experiment. In propolis group, the score improved from $42.78 \pm 10.02$ in month 0 to $47.05 \pm 4.04$ and $47.71 \pm 0.87$ in month 3 and month 6 respectively. However, the analysis of this improvement in PCS was not statistically significant $(p=0.09)$. While in placebo group, the improvement of PCS scores $(35.99 \pm 13.69$ in month 0 to $48.09 \pm 5.24$ in month 3 and $48.54 \pm 4.99$ in month 6 was statistically significant.

A better result can be seen in MCS. The MCS in both propolis and placebo group was categorized as good with the mean score of MCS was above 50. The MCS in the beginning of study were $65.01 \pm 4.41$ in propolis group and $66.15 \pm 4.83$

Table 4. Subjects' clinical symptoms before and after the teatment.

\begin{tabular}{|c|c|c|c|c|c|c|c|c|c|}
\hline \multirow{3}{*}{ Clinical Symptoms } & \multicolumn{3}{|c|}{ Month 0} & \multicolumn{3}{|c|}{ Month 3} & \multicolumn{3}{|c|}{ Month 6} \\
\hline & \multicolumn{2}{|c|}{ n (\%) } & \multirow[b]{2}{*}{$p$-value } & \multicolumn{2}{|c|}{ n (\%) } & \multirow[b]{2}{*}{$p$-value } & \multicolumn{2}{|c|}{ n (\%) } & \multirow[b]{2}{*}{$p$-value } \\
\hline & $\begin{array}{c}\text { Propolis } \\
(n=19)\end{array}$ & $\begin{array}{c}\text { Placebo } \\
(n=24)\end{array}$ & & $\begin{array}{c}\text { Propolis } \\
(n=19)\end{array}$ & $\begin{array}{c}\text { Placebo } \\
(n=24)\end{array}$ & & $\begin{array}{c}\text { Propolis } \\
(n=19)\end{array}$ & $\begin{array}{c}\text { Placebo } \\
(n=24)\end{array}$ & \\
\hline Diarrhea & $0(0)$ & $1(4.17)$ & 1.00 & $0(0)$ & $0(0)$ & - & $0(0)$ & $0(0)$ & - \\
\hline Nausea and vomiting & $5(26.32)$ & $6(25.00)$ & 1.00 & $1(5.26)$ & $1(4.17)$ & 1.00 & $1(5.26)$ & $1(4.17)$ & 1.00 \\
\hline Losing body Weight & $631.58)$ & $7(29.17)$ & 1.00 & $0(0)$ & $1(4.17)$ & 1.00 & $0(0)$ & $1(4.17)$ & 1.00 \\
\hline Fever & $5(26.32)$ & $3(12.50)$ & 0.70 & $1(5.26)$ & $1(4.17)$ & 1.00 & $0(0)$ & $1(4.17)$ & 1.00 \\
\hline Cough/shortness of breath & $3(15.79)$ & $6(25.00)$ & 0.46 & $0(0)$ & $0(0)$ & - & $0(0)$ & $1(4.17)$ & 1.00 \\
\hline Skin rash & $1(5.26)$ & $0(0)$ & 1.00 & $0(0)$ & $0(0)$ & - & $0(0)$ & $0(0)$ & - \\
\hline
\end{tabular}


Table 5. SF-12 analysis for physical and mental health score.

\begin{tabular}{cccccc}
\hline \multirow{2}{*}{ Score } & \multirow{2}{*}{ Month } & \multicolumn{2}{c}{ Propolis } & \multicolumn{2}{c}{ Placebo } \\
\cline { 2 - 6 } & & Mean \pm SD & $p$-value & Mean \pm SD & $p$-value \\
\hline \multirow{3}{*}{ PCS } & 0 & $42.78 \pm 10.02$ & & $35.99 \pm 13.69$ & \\
& 3 & $47.05 \pm 4.02$ & 0.06 & $48.09 \pm 5.24$ & 0.01 \\
& 6 & $47.71 \pm 0.87$ & & $48.54 \pm 4.99$ & \\
\hline \multirow{2}{*}{ MCS } & 0 & $65.01 \pm 4.41$ & & $66.16 \pm 4.83$ & \\
& 3 & $64.7 \pm 3.59$ & 0.09 & $64.16 \pm 3.16$ & 0.02 \\
& 6 & $63.11 \pm 2.5$ & & $63.81 \pm 2.51$ & \\
\hline
\end{tabular}

in placebo group. Throughout the study, mental health score in propolis group was remain stable $(64.70 \pm+3.59$ in month 3 and $63.11 \pm 2.50$ in month 6), while in placebo group the score has declined significantly $(64.16 \pm 3.16$ in month 3 and $63.81 \pm 2.51$ in month $6, p=0.02$ ).

\section{The Adverse Events During the Study}

There were mild adverse events experienced by 3 subjects in this study. The subjects were instructed to stop the supplementation immediately. The details of subjects who experienced the adverse events as follow: Subject 1, a 48-year-old woman, with baseline CD4 94 cell/ $\mu \mathrm{L}$, got nausea, vomiting, and palpitations after taking propolis 2 days. Once the propolis was stopped, the symptoms improved; Subject 2, a 51-year-old male, with baseline CD4 685 cell $/ \mu \mathrm{L}$, complained of itching and hiccup on the neck, face and hands after consuming propolis for 8 weeks. Propolis was discontinued and the symptoms improved with anti histamine therapy; Subject 3, a 35-year-old woman, with baseline CD4 130 cell $/ \mu \mathrm{L}$ complained of coughing and palpitations after receiving 10 weeks of propolis. The subject stopped the propolis and the symptoms improved without specific therapy. All symptoms of those adverse events were not life threatening and all the subjects were in good condition until the research finished.

\section{Discussion}

\section{The Research Subjects' Characteristics}

The subjects in this study were people living with HIV in stage 1 or stage 2 of WHO clinical criteria. The average age in both groups were 36.8 and 37.1 years old for propolis and placebo group respectively. The age range between 18 to 51 years old. It was in line with the demographic data for the average age of the patients living with HIV in Asia, 37.07 years old.(12)

Propolis supplementation has a neutral effect on body weight of the patients living with HIV on ARV treatment as there was no significant difference in body weight at the beginning and the end of the research. It is also accordance with a study on giving propolis in patients with virus infections, which reported that there was no difference in body weight (13) and not associated with diminished CD4 cell (14).

\section{Total CD4 Cell Cefore and After Supplementation}

Baseline CD4 cell in both groups where far below normal limit. The specific characteristics of HIV infection was progressive depletion of CD4 cells. It could drop to below 200 cells $/ \mu \mathrm{L}$ that were strongly related to the cellular immunity disorder and increased the susceptibility to the opportunistic infections.(15) The depletion of CD4 could be caused by the direct effects of the virus and the indirect effects of the body's defense system. The direct effect was occurred due to the absence of cell membrane integrity caused by viral budding, virus DNA accumulation that was not integrated, the process of gp120-CD4 auto fusion, and syncytium formation. Meanwhile, the indirect mechanisms in reducing CD4 were the divergence of intracellular signaling, autoimmunity mechanism, the process of cell death (apoptosis), pyroptosis, autophagy, and the inhibition of lymphopoiesis. $(16,17)$

Data from the previous studies, the normal CD4 count was 865 (430-1740) cells $/ \mu \mathrm{L}$ in healthy population in India (18), 744 (237-1.616) cells/ $\mu \mathrm{L}$ in Asia population, and 828 (259-1.919) in non-Asian healthy population (19). In this study, CD4 cell inclined throughout the study period. This inclined was statistically significant in propolis group after 3 months propolis administration $(p=0.024)$. However, this increment was not significant when propolis was continued for 6 months. Propolis contains more than 300 constituents (4), of which were proven might inhibit HIV replication enzymes (5). Some of the active compounds from propolis that are reported to have anti-HIV activity include flavonoids (20), moronic acid (21) and caffeic acid (22). An in vitro study reported that anti HIV effect of propolis was by suppressing viral replication in the way of decreasing p24 
antigen production in a concentration-dependent manner. (23) Another study reported that propolis suppressed HIV virus expression in CD4 $\mathrm{T}$ lymphocyte and microglia cell cultures by inhibiting viral fusion in target cells. The addition of propolis to standard ARV drugs (zidovudin) might increase the potential action of Zidovudin.(5)

One study about supplementation of honey, a bee product similar to propolis, in human HIV subjects without $\mathrm{ARV}$, reported that there were significant reductions in CD4 cell in group with low dose (20 g) honey and without honey, while in group with moderate and high dose honey ( $40 \mathrm{~g}$ and $60 \mathrm{~g}$ respectively), the reduction of CD4 cell were not significant. It might impaired that honey may prevent the sharp decline of CD4 cell in non-ARV HIV subjects.(24)

To date, there is limited scientific article which reported the effect of propolis supplementation in HIV subjects. As it is the first paper, in our concerns, therefore, it is too premature to figure out the direct or indirect effect of propolis on human CD4 cell. CD4 is part of human immune adaptive. It needs to be stimulated to modulate the specific gene expression, which will lead to the activation of innate immunity and the development of adaptive immune responses.(25) In HIV, this response has been widely disturbed.

The increase of CD4 cell is associated with a number of factors. It was reported that older age, a low nadir CD4, a long duration of the HIV infection before ARV initiation and coinfection with hepatitis $\mathrm{C}$ predispose to failure immunological nonresponse. From all of those parameters, the CD4 nadir specifically seems to be predominant for the raising of CD4 cells.(26) CD4 nadir of subjects were very low, $128.42 \pm 111.08$ cells $/ \mu \mathrm{L}$ in propolis group and $129.58 \pm 115.75$ cells $/ \mu \mathrm{L}$ in placebo group.(27) This factor could be contributed to the slow-moving of CD4 increment. Other factors that influence the CD4 improvement and was not identified by the researcher were HIV and ARV duration, time of ARV initiation, the level of viral load when ARV started. $(28,29)$

\section{Blood Profile Before and After Supplementation}

This study examined the profile of routine blood tests, which were hemoglobin, leukocyte, and platelets. The result shows that no significant difference of these parameters in both groups at the beginning and the end of the research. This shows that propolis and placebo do not alter the levels of hemoglobin, leukocyte, and platelets, same as previous research.(30) A study in irradiated animal model which given propolis showed that propolis might significantly improve $\mathrm{Hb}$ concentration, leukocytes and platelets to almost near normal values when compared with normal animals.(31) It may impair that propolis does not harm and safe to be used in term of blood profiles ( $\mathrm{Hb}$, leukocytes and platelet).

\section{Clinical Condition and Quality of Life of Subjects Before and After Supplementation}

Some of the subject reported an improvement in subjective complaints and clinical symptoms, however, the analysis of this finding did not show a significant different between pre and post treatment. It may be caused the subjects involved in this study were asymptomatic HIV patients, therefore their health condition was in a good and stable conditions since from the beginning of study throughout the experiment period. It also can be concluded that propolis did not cause harmful effect in term of subjective complaint and clinical symptoms.

The data of health status using SF-12 showed that the PCS in the propolis group and placebo group was categorized as fair. It can be inferred that HIV lead the patients to become immunocompromised and susceptible to unhealthy condition. The MCS results was better than PCS in both the propolis and the placebo. It might be considered that propolis supplementation was not directly affect the physical and mental health status in HIV patient. It has a neutral effect on the quality of life (both physical and mental) of asymptomatic HIV patients with ARV.

\section{The Adverse Events During the Study}

During the research, 3 subjects from the propolis group were supposed to experience adverse events. Propolis was reported safe to be consumed and had a high toxic dose and lethal dose.(32) There was limited data on propolis allergy in HIV subject. One case was reported in 40-yearold female who experienced a painful mouth ulcer after taking propolis for 15 days. Her symptoms abated in a few days after stopping taking propolis.(33) There were several reports showed that there were fatal side effects in animals and people. They were assumed to be allergic to honey or to the allergen of the flowers where the bees took the pollen. $(34,35)$ The allergens that ever reported were 3-Methyl-2-butenyl (E)-caffeate and Phenylethyl caffeate which was the substances in the poplar type propolis.(35) The manifestation of allergy could be as contact dermatitis or oral mucositis, usually occur in beekeepers.(36)

The use of supplements had been widely used in patient with HIV and other chronic diseases and had been reported to be safe based on testimonials from users without any clear and scientific evidence. The adverse events that 
happened in this research were the things that should be alerted and the important notes in educating the patients about the use of propolis along with ARV.

The thing that still became a challenge is the scientific evidence stating that propolis gave a benefit for HIV patients. Morever, propolis becomes a part of health promotion spread in the community for its benefits for the body's immune system. Meanwhile, there was no sufficient evidence about the safety profile for the body, and how propolis constituent interacted with the standard ARV drug. Hence, the proper communication and concise education to the patients about the use of propolis in top of ARV should be delivered appropriately. This research proved that propolis did not influence the increase of CD4 cell in HIV patients.

The normal value of CD4 leukocyte count is 400-1600 cells $/ \mu \mathrm{L}$, so it is very possible that the propolis has no effect on changes in CD4 lymphocyte counts above 400 cells $/ \mu \mathrm{L}$. From these assumptions, the next research is expected to focus on analyzing the effect of propolis on HIV patients receiving $\mathrm{ARV}$ with a $\mathrm{CD} 4$ count $<400$ cells $/ \mu \mathrm{L}$.

\section{Study Limitations}

This study was applied to the patients living with HIV without concerning the total CD4, the duration of HIV infection, and the various types of ARV among patients so that there are a wide range and heterogeneous data and it could not reflect the specific HIV population because of different starting points. There were also confounding variables that were not assessed, such as Hepatitis B, Hepatitis C, cytomegalovirus, and toxoplasmosis.

Screening process in this study was done by conducting anamnesis, physical examination, and simple supporting assessments. The determination of HIV stages and opportunistic infections were made based on the criteria of simple diagnosis which was adopt from WHO clinical staging of HIV.(10) Once the subject has no clinical sign and symptoms of clinical stage 3 or 4 (such as chronic diarrhoea, persistent fever, oral candidiasis, PCP, extrapulmonary tuberculosis), they would be included to the study. Thus, there was a possibility of an inaccurate diagnosis.

Other factor that could not be controlled was dietary patterns as subjects were living in their own homes, hence it was difficult to equalize the dietary pattern among them. This study did not evaluate the parameter of the organ functions related to the metabolism of propolis and propolis levels in the plasma because of limited resources and laboratory facilities. Consequently, the effects of the supplement in several related organs could not be monitored in detail.

\section{Conclusion}

Based on the result of this study, the administration of propolis on HIV patients receiving ARV bring signifacnt difference in the increase of CD4 in propolis group from baseline to 3 month after the treatment. While in placebo group, this increment was not significant. At the end of study, CD4 count continued to rise up, however the increase was not statistically significant. There are no hemoglobin, leukocyte, platelets, and quality of life abnormalities. Therefore, it is necesary to do further research with a spesific CD4 count. However, it may be beneficial in relieving the clinical symptoms and quality of life of patient living with HIV.

\section{Authors Contribution}

EAT coordinated the research as a lead researcher. SF coordinated field inspections of respondents as a field manager. LM processed the epidemiology and HIV/AIDS data as an epidemiologist. HP, JS, JH, and IH discussed the the characteristics of the HIV, hosts of HIV, and the benefits of bee products for HIV patients.

\section{References}

1. Halpin SN, Carruth EC, Rai RP, Edelman EJ, Fiellin DA, Gibert C, et al. Complementary and alternative medicine among persons living with HIV in the era of combined antiretroviral treatment. AIDS Behav. 2018; 22: 848-52.

2. Endale Gurmu A, Teni FS, Tadesse WT. Pattern of traditional medicine utilization among HIV/AIDS patients on antiretroviral therapy at a university hospital in northwestern Ethiopia: a crosssectional study. Evid Based Complement Alternat Med. 2017; 2017: 1724581. doi: 10.1155/2017/1724581.

3. Cichello S, Tegegne SM, Yun H. Herbal medicine in the management and treatment of HIV-AIDS-A review of clinical trials. Aust J Herb Med. 2014; 26: 100.

4. Silva-Carvalho R, Baltazar F, Almeida-Aguiar C. Propolis: a complex natural product with a plethora of biological activities that can be explored for drug development. Evid Based Complement Alternat Med. 2015; 2015: 206439. doi: 10.1155/2015/206439.

5. Gekker G, Hu S, Spivak M, Lokensgard JR, Peterson PK. AntiHIV-1 activity of propolis in CD4+ lymphocyte and microglial cell cultures. J Ethnopharmacol. 2005; 102: 158-63.

6. Silva CCF, Salatino A, Motta LB, Negri G, Salatino MLF. Chemical characterization, antioxidant and anti-HIV activities of a Brazilian propolis from Ceará state. Revista Brasileira de Farmacognosia. 2019; 29: 309-18

7. Olivero-Verbel J, Pacheco-Londoño L. Structure-activity relationships for the anti-HIV activity of flavonoids. J Chem Inform Comput Sci. 2002; 42: 1241-6. 
8. Fesen MR, Pommier Y, Leteurtre F, Hiroguchi S, Yung J, Kohn KW. Inhibition of HIV-1 integrase by flavones, caffeic acid phenethyl ester (CAPE) and related compounds. Biochem Pharmacol. 1994; 48: 595-608.

9. Erdemli HK, Akyol S, Armutcu F, Akyol O. Antiviral properties of caffeic acid phenethyl ester and its potential application. J Intercult Ethnopharmacol. 2015; 4: 344-7.

10. World Health Organization. WHO Case Definitions of HIV for Surveillance and Revised Clinical Staging and Immunological Classification of HIV-related Disease in Adults and Children. Geneva: World Health Organization; 2007.

11. Ware Jr JE, Kosinski M, Keller SD. A 12-Item Short-Form Health Survey: construction of scales and preliminary tests of reliability and validity. Med Care. 1996: 34: 220-33.

12. Petoumenos K, Choi JY, Hoy J, Kiertiburanakul S, Ng OT, Boyd M, et al. CD4:CD8 ratio comparison between cohorts of HIV-positive Asians and Caucasians upon commencement of antiretroviral therapy. Antivir Ther. 2017: 22: 659-68.

13. Soroy L, Bagus S, Yongkie IP, Djoko W. The effect of a unique propolis compound (Propoelix ${ }^{\mathrm{TM}}$ ) on clinical outcomes in patients with dengue hemorrhagic fever. Infect Drug Resist. 2013; 7: 323-9.

14. Feleke D, Yemanebrhane N, Gebretsadik D. Nutritional status and CD4 cell counts in HIV/AIDS patients under highly active antiretroviral therapy in Addis Ababa, Ethiopia. J AIDS Clin Res. 2017; 18: 2-4.

15. Okoye AA, Picker LJ. CD4+ T-cell depletion in HIV infection: mechanisms of immunological failure. Immunol Rev. 2013; 254: 54-64.

16. Maartens G, Celum C, Lewin SR. HIV infection: epidemiology, pathogenesis, treatment, and prevention. Lancet. 2014; 384: 258-71.

17. Abbas AK, Lichtman AH, Pillai S. Congenital and acquired immunodefciencies. In: Cellular and Molecular Immunology. 7th ed. Philadelphia: Elsevier Health Sciences; 2012. p. 445-70.

18. Uppal S, Verma S, Dhot P. Normal values of CD4 and CD8 lymphocyte subsets in healthy indian adults and the effects of sex, age, ethnicity, and smoking. Cytometry B Clin Cytom. 2003; 52: 32-6.

19. Howard RR, Fasano CS, Frey L, Miller CH. Reference intervals of $\mathrm{CD} 3, \mathrm{CD} 4, \mathrm{CD} 8, \mathrm{CD} 4 / \mathrm{CD} 8$, and absolute CD4 values in asian and non-asian populations. Cytometry. 1996; 26: 231-2.

20. Xu HX, Wan M, Dong H, But PPH, Foo LY. Inhibitory activity of flavonoids and tannins against HIV-1 protease. Biol Pharm Bull. 2000; 23: 1072-6.

21. Ito J, Chang FR, Wang HK, Park YK, Ikegaki M, Kilgore N, et al. Anti-HIV activity of moronic acid derivatives and the new melliferone-related triterpenoid isolated from Brazilian propolis. $\mathrm{J}$ Nat Prod. 2001; 64: 1278-81.

22. Zhang X, Neamati N, Lee YK, Orr A, Brown RD, Whitaker N, et al. Arylisothiocyanate-containing esters of caffeic acid designed as affinity ligands for HIV-1 integrase. Bioorg Med Chem. 2001; 9:
1649-57.

23. Harish Z, Rubinstein A, Golodner M, Elmaliah M, Mizrachi Y. Suppression of HIV-1 replication by propolis and its immunoregulatory effect. Drugs Exp Clin Res. 1997; 23: 89-96.

24. Yusuf WNW, Mohammad WMZW, Gan SH, Mustafa M, Abd Aziz CB, Sulaiman SA. Tualang honey ameliorates viral load, CD4 counts and improves quality of life in asymptomatic human immunodeficiency virus infected patients. J Tradit Complement Med. 2019; 9: 249-56.

25. Hermawan AG. Development of immunopathobiogenesis on SIRSsepsis. Indones Biomed J. 2009; 1: 32-9.

26. Gaardbo JC, Hartling HJ, Gerstoft J, Nielsen SD. Incomplete immune recovery in HIV infection: mechanisms, relevance for clinical care, and possible solutions. Clin Dev Immunol. 2012; 2012: 670957. doi: 10.1155/2012/670957.

27. Triyono EA, Firdausa S, Prasetyo H, Susanto J, Hutagalung JS, Masyfufah L, et al. The effect of propolis supplementation to CD4/ CD8 ratio in HIV-infected patients receiving ARV therapy. New Armen Med J. 2019; 13: 85-94.

28. Tinago W, Coghlan E, Macken A, McAndrews J, Doak B, PriorFuller $\mathrm{C}$, et al. Clinical, immunological and treatment-related factors associated with normalised $\mathrm{CD} 4+/ \mathrm{CD} 8+\mathrm{T}$-cell ratio: effect of naive and memory T-cell subsets. PloS one. 2014; 9: e97011. doi: 10.1371/journal.pone.0097011.

29. Serrano-Villar S, Moreno S, Fuentes-Ferrer M, Sánchez-Marcos C, Avila M, Sainz T, et al. The CD 4: CD 8 ratio is associated with markers of age-associated disease in virally suppressed HIVinfected patients with immunological recovery. HIV Med. 2014; 15: 40-9.

30. Parinitha S, Kulkarni M. Haematological changes in HIV infection with correlation to CD4 cell count. Australas Med J. 2012; 5: 157 62.

31. Muhammad M, Mouchira M, Naglaa R. Physiological effects of bee venom and propolis on irradiated albino rats. Danish J Agricult Animal Sci. 2015; 2015: 11-21.

32. Yildirim A, Duran GG, Duran N, Jenedi K, Bolgul BS, Miraloglu $\mathrm{M}$, et al. Antiviral activity of hatay propolis against replication of herpes simplex virus type 1 and type 2. Med Sci Mon Int Med J Exp Clin Res. 2016; 22: 422-30.

33. Bellegrandi S, D'Offizi G, Ansotegui IJ, Ferrara R, Scala E, Paganelli R. Propolis allergy in an HIV-positive patient. J Am Acad Dermatol. 1996; 35: 644. doi: 10.1016/S0190-9622(96)90702-1.

34. Callejo A, Armentia A, Lombardero M, Asensio T. Propolis, a new bee-related allergen. Allergy. 2001; 56: 579. doi: 10.1034/j.13989995.2001.056006579.x.

35. Lieberman HD, Fogelman JP, Ramsay DL, Cohen DE. Allergic contact dermatitis to propolis in a violin maker. J Am Acad Dermatol. 2002; 46: S30-S1.

36. Miguel MG, Antunes MD. Is propolis safe as an alternative medicine? J Pharm Bioallied Sci. 2011; 3: 479-95. 